\title{
Growth Inhibitory and Quinone Reductase Activity Stimulating Effects of Internal Organs of Aplysia kurodai Fractions on Cancer Cell Lines In vitro
}

\author{
Mi-Ok Shin* \\ Dept. of Food and Nutrition, Silla University, Busan 617-736, Korea \\ Received February 17, 2010 / Accepted March 30, 2010
}

\begin{abstract}
We investigated the growth inhibitory effect of internal organs of Aplysia kurodai (AK) on proliferation in cancer cell lines in vitro. The internal organs of AK were extracted with methanol (AKM), which were then further fractionated into four subfractions by using solvent partition method, resulting in hexane (AKMH), methanol (AKMM), butanol (AKMB), and aqueous (AKMA) soluble fractions. We determined the cytotoxic effect of these four fractions in four kinds of cancer cell lines - HepG2, MCF-7, HT29 and B16-F10 - by MTT assay. Among the four subfractions of AKM, AKMM showed the strongest cytotoxic effects on all cancer cell lines which were used. Morphological changes such as membrane shrinking and blebbing of cells were also observed in AKMM treatment in HepG2 cells. In addition, we also observed quinone reductase (QR) induced effect in the methanol layer (AKMM) of HepG2 cells. AKMM showed the highest induction activity of quinone reductase on HepG2 cells among the partition layers. The QR induced effect of AKMM was determined to be 2.4 at $100 \mu \mathrm{g} / \mathrm{ml}$ level with a control value of 1.0. Although further studies are needed, the present work suggests that internal organs of Aplysia kurodai (AK) may be a chemopreventive agent for the treatment of human cells.
\end{abstract}

Key words : Growth inhibitory effect, quinone reductase, internal organs of Aplysia kurodai (AK)

\section{서 론}

암은 식습관, 자극물, 화학물질, 방사성 물질 및 바이러스 인자와 같은 환경적요인과 유전적 요소, 노화 및 호르몬의 부 조화 등의 내인성 요인이 관여하여 인체가 가지는 적절한 세 포 사멸과 분화, 성장의 조절 메커니즘을 방해함으로써 세포 의 비정상적이고 무절제한 증식을 이끌면서 세포수의 균형을 무너뜨려 마침내 다른 조직에 침투되는 질병이라고 알려져 있다[3,16]. 최근 암의 발생 원인과 발생기전을 해명하고 치료, 예방하려는 연구가 많이 진행되고 있으며 암 백신[2], 면역요 법[8], 생물학적 제재[4] 등이 제시되고 있으나 좀 더 적극적인 예방법 즉, 암 화학예방(chemoprevention)에 대해 많은 관심 이 재고되고 널리 연구 중에 있다. 대표적인 암 예방 기전의 연구에 사용하는 생화학적 분석 방법은 체내 독성물질이나 발암물질을 무독화 시키는 phase $\Pi$ 효소인 quinone reductase $(\mathrm{QR})$ 와 glutathione S-transferase (GST) 활성유도와 phase I 효소인 cytochrome P450 효소 활성 억제, glutathione 생성, transformed cell에서 그 함량이 증가되는 polyamine 생성억제 등의 측정이 있다[6]. QR은 간세포에서 주로 생성되는 phase II enzyme의 한 종류로 quinone을 환원시켜 무독하게 만들고 세포내에 유도되어 여러 돌연변이 물질에

\footnotetext{
*Corresponding author

Tel : +82-51-999-6272, Fax : +82-51-999-5457

E-mail : shinmo@silla.ac.kr
}

의해 일어나는 돌연변이와 종양화를 막아주고 발암물질을 무 독하게 하는 역할을 한다[34]. 암 화학예방은 암의 발생을 예방 하거나 암화 과정을 천천히 진행시키는 제제나 천연 화합물을 섭취함으로서 심각한 암이나 질병을 발생하는 위험부담을 줄 이는 것이다[14]. 따라서, 많은 연구자들은 독성을 가지지 않고 안전하게 암을 치료할 수 있는 새로운 천연소재의 치료제와 기능성 식품을 개발하기 위해 천연물질에 관심을 갖고 있다.

이와 같이 천연 소재의 원천으로 바다를 들 수 있는데, 지구 상에 남아 있는 마지막 자원의 보고인 해수 중에는 50 만종 이상의 풍부한 해양생물이 폐쇄계의 독특한 환경에 적응하면 서 살아가고 있다. 또한 최근 들어 항 발암 효과에 대한 연구가 육상 생물에서뿐만 아니라 해양 생물에서 활발한 연구가 진행 되고 있으며[27] 특히, 해양생물은 육상생물에 없는 특유의 대 사과정으로 인하여 다양한 신규생리활성물질의 탐색 가능성 을 가지고 있어 미지의 천연물질 개발에 기대가 높이 평가되 고 있다[21]. 또한 이러한 해양생물 중 해조류와 같은 해양식물 종들의 다양한 생리활성들이 밝혀지고 있는 가운데, 해양 동 물 종들에 대한 연구 또한 관심의 대상이 되고 있다. 그러나 이러한 다양한 종의 해양 동물이 있음에도 불구하고 생리활성 의 연구가 진행되고 있거나 연구가 수행되어진 것은 드문 실 정이다. 현재까지 발표된 해양 동물의 생리활성으로는 불가사 리, 성게껍질과 우렁쉥이껍질, 해삼 등으로부터 분리된 해삼 당단백질과 황산 콘드로이친, 렉틴 등의 생리활성 물질이 항 돌연변이 및 항암효과, 항산화, 항균 효과를 가진다는 보고 
등이 있다[32]

본 연구에 사용되어진 군소(Aplysia kurodai)는 무순목 군소 과에 속하는 연체동물로, 우리나라와 일본, 대만 등지의 조간 대 얕은 바다에서 주로 서식하고 있으며, 먹이가 되는 홍조류, 갈조류 및 녹조류 등의 해조류가 무성한 바위근처에서 주로 볼 수 있다[7]. 흑갈색에 회백색 얼룩무늬가 많으며 몸을 보호 하는 패각 대신 군청색 색소를 뿜어 자신을 보호하는 특징을 가지며, 일반적으로 조리 시 내장과 보라색 색소를 빼내고 삶 아 군소몸통을 먹으며, 경상도 해안지방에서는 제사상에도 올 려진다. 그리고 군소 체중의 약 $50 \%$ 나 되는 생식기관을 포함 한 내장부분은 거의 대부분 폐기되어진다. 한편, 군소는 단순 한 신경계와 동정이 쉬운 거대 뉴런을 지니고 있어 신경생물 학 연구에 중요한 실험동물로 이용되고 있고, 미국에서는 군 소의 신경계를 이용하여 학습과 기억에 대한 연구가 꾸준히 진행되고 있다[11]. 국내에서도 세계적 추세에 따라 군소의 신 경 생물학적 연구가 절실히 요구되고 있으나 현재까지의 군소 에 대한 연구는 아주 미비하며 단순히 분류나 분포 등에 관한 생태학적 보고가 되고 있을 뿐이다[7,13,15]. 특히, 우리나라 연근해에 서식하는 군소는 식용 이외에는 거의 이용이 없는 실정이며, 군소에 대한 생물학적 기초 연구는 표지(Tagging) 를 이용한 조간대 군소의 성장에 대한 연구[19], 개체크기와 난의 크기와의 관계에 대한 연구[33]등과 군소의 중추신경계 를 이용한 $\mathrm{SCP}_{\mathrm{S},}$ Buccalin, myomodulin 등의 신경성 펩타이드 에 대한 연구 $[12,17,18]$ 등에 불과하다. 그리고 군소가 가지는 생리 활성 성분에 대한 연구는 아직 미흡한 실정이다.

본 연구에서는 폐기 되어지는 군소 부산물인 군소 내장을 이용하여, 암세포 성장 억제 효과를 MTT assay를 이용하여 알아보았고, 암 예방 물질 탐색에 사용되어지는 quinone reductase $(\mathrm{QR})$ 유도 활성 증가 효과를 측정하여 암 예방 효과를 검토하여 발암 억제 효과를 가진 기능성 식품으로서의 개발 가능성을 알아보고자 하였다.

\section{재료 및 방법}

\section{실험재료}

본 실험에 사용된 군소내장(internal organs of Aplysia kurodai, AK)은 2008년 3월 부산 해운대 연안에서 구입하였다. 세 포실험에 사용된 시약 중 NP-40과 3-[4,5-dimethylthiazol2-yl]-2,5-diphenyltetrazolium bromide (MTT)와 menadione 은 Sigma사 제품을 구입하였고 flavin adenine dinucleotide (FAD), dicumarol 및 glucose-6-phosphate dehydrogenase는 Amresco사 제품을 구입하였으며, minimum essential medium (MEM), Dulbeco's Eagle modified medium (DMEM) 과 phosphate buffered saline (PBS) 등은 Gibco-BRL (USA) 에서 구입하였다. 그 외 연구에 사용된 용매 및 시약은 특급을 사용하였다.

\section{시료의 추출 및 분획물 제조}

시료로 사용된 군소내장은 수세, 건조하여 분쇄한후 메탄올 을 $1: 5(\mathrm{~W} / \mathrm{V})$ 의 비율로 첨가하여 상온에서 2회 추출하고, 극 성과 비극성으로 선별물질을 추출하기 위하여 다시 메탄올과 다이클로로메탄 $\left(\mathrm{CH}_{2} \mathrm{Cl}_{2}\right)$ 을 1:1로 섞은 용액에 2회 추출한 후 회전식 진공농축기로 일정시간 감압 농축시켜 동결건조한 후 군소내장 methanol추출물(AKM)을 얻었다. 이 추출물을 hexane층(AKMH), methanol층(AKMM), butanol층(AKMB) 및 aqueous층(AKMA)으로 나누어 비극성에서 극성으로 계통 분 획하고 각 분획층을 감압 농축 후 동결 건조하여 분말로 만들 어 시료로 사용하였다.

\section{세포배양}

본 실험에 사용한 암세포주는 인체 간암 세포인 HepG2 (Human hepatocellular carcinoma), 유방암 세포인 MCF-7 (Human breast adenocarcinoma pleural effusion), 대장암 세 포인 HT-29 (Human colon adenocarcinoma) 및 마우스 유래 의 피부암세포주인 B16-F10 (mouse melanoma)로서 2005년 6월 한국세포주은행으로부터 분양받아 사용하였다.

HepG2, MCF-7, B16-F10 세포주는 DMEM medium을 사용 하였고 HT-29 세포주는 RPMI1640을 사용하였으며 medium 에 $10 \%$ 의 fetal bovine serum (FBS)와 1\% 100 units $/ \mathrm{ml}$ 의 penicillin streptomycin이 함유된 것으로 T-75 flask에 이식한 후 $37^{\circ} \mathrm{C}, 5 \% \mathrm{CO}_{2}$ incubator에서 monolayer로 배양하였다. 위의 3 종의 세포주는 일주일에 2 3회 정도 새로운 배지로 교환하 고 flask에 암세포주가 $5 \times 10^{4}$ cells $/ \mathrm{ml}$ 정도 증식되면 phosphate buffered saline (PBS, pH 7.0)으로 2번 세척한 후 tryp$\sin -\mathrm{EDTA}$ 를 처리하여 바닥에서 세포를 분리한 후, 배양액으 로 암세포가 골고루 분산되도록 희석하여 T-75 flask에 $10 \mathrm{ml}$ 씩 분할하여 주입하고 4 5일마다 계대배양하면서 실험에 사 용하였다. 계대 배양시 각각의 passage number가 10회 이상일 때는 액체질소탱크로부터 새로운 세포를 꺼내어 다시 배양하 여 실험하였다.

\section{암세포 성장 억제 효과(Cytotoxicity) 측정}

군소내장 분획물의 암세포 증식억제효과는 MTT assay를 사용하여 행하였다. MTT (3-[4,5-dimethylthiazol-2-yl]-2,5-diphenyltetrazolium bromide) [1,5] assay는 세포의 생육을 측 정하는 방법으로서 살아있는 세포의 미토콘드리아 내의 dehydrogenase가 황색 수용성 물질인 MTT에 의해 dark blue formazan을 생성하는 원리를 이용하였다.

이를 위해 각 세포주는 $1 \times 10^{5}$ cells/well의 농도로 맞추고 24 well에 각각 $1 \mathrm{ml}$ 씩 첨가하여 24 시간동안 $37^{\circ} \mathrm{C}, 5 \% \mathrm{CO}_{2}$ incubator에 배양한 후 용매종류별 분획물을 각각 일정량의 dimethyl sulfoxide (DMSO)에 녹여서 50, 100, 150, 200, 250 $\mathrm{\mu g} / \mathrm{ml}$ 의 농도로 첨가하였다. 일정시간 동안 배양한 후 각 
well에 PBS 완충액에 녹인 MTT 용액을 $100 \mu \mathrm{l}$ 씩 첨가하여 4 시간동안 다시 배양시킨 후, well 바닥에 형성된 formazan이 흐트러지지 않게 상등액을 제거하고 $\mathrm{DMSO}$ 와 ethanol을 1:1 로 혼합한 용액을 $1 \mathrm{ml}$ 를 첨가하여 천천히 녹인 후 Multi-detection microplate를 이용하여 $570 \mathrm{~nm}, 690 \mathrm{~nm}$ 에서 측정하였 다. 대조군 세포수를 $100 \%$ 로 정하고 상대적인 세포성장 억제 율을 구하였다.

\section{위상차 현미경을 이용한 세포형태학적 관찰}

세포배양용 petridish에 각각의 암세포주를 24 시간 동안 안 정화시킨 다음 군소내장 분획물을 농도별로 처리하여 48 시간 동안 배양한 후, 위상차 현미경을 이용하여 200배의 배율로 각 농도에 따른 형태의 변화를 관찰한 후에 Olympus DP70을 이용하여 촬영하였다.

\section{Quinone reductase (QR) 유도 활성 측정}

Quinone reductase는 phase II 무독화 효소 중의 하나로 돌연변이 또는 발암물질 등에 의한 DNA와의 상호 작용을 차 단하는 효소이며, $\mathrm{NAD}(\mathrm{P}) \mathrm{H}$ 를 이용하여 quinone류의 환원을 촉매하는 flavoprotein이다[9,25,26].

$\mathrm{QR}$ 생성 유도 효과는 Prochaska와 Santamaria [20,24]의 방 법을 일부 변형하여 측정하였다. T-75 flask의 세포가 $80 \%$ 이 상 증식하게 되면 24 well plate의 각 well에 $1 \times 10^{4}$ cells $/ \mathrm{ml}$ 되 도록 HepG2 세포주를 분주하여, incubator에 24시간동안 배 양한 후 오징어내장 분획물을 $\mathrm{HepG} 2$ 의 세포생존율이 $50 \%$ 되 는 양을 final 농도로 잡아 각각 DMSO에 녹여 20, 40, 60, 80 및 $100 \mu \mathrm{g} / \mathrm{ml}$ 의 농도로 첨가하고 다시 24시간동안 배양한 다 음 배양액을 제거하였다. 배지가 제거된 각 well에 $250 \mu \mathrm{l}$ 의 lysis buffer (10 mM Tris-Cl, pH 8.0, $14 \mathrm{mM} \mathrm{NaCl}, 15 \mathrm{mM}$ $\mathrm{MgCl}_{2}, 0.5 \% \mathrm{NP}-40$ )를 첨가한 후 $37^{\circ} \mathrm{C}, 5 \% \mathrm{CO}_{2}$ incubator에 10 분간 두면서 cell을 lysis한 후 reaction mixture 즉, $10 \mathrm{mM}$ Tris-Cl (pH 7.4), 0.5 mg/ml BSA, 0.008\% tween-20, $40 \mu \mathrm{M}$ FAD, $0.8 \mathrm{mM}$ glucose-6-phosphate, $2 \mathrm{Unit} / \mathrm{ml}$ glucose-6-phosphate dehydrogenase, $25 \mu \mathrm{M}$ NADP, $40 \mu \mathrm{g} / \mathrm{ml}$ MTT 및 $1 \mathrm{mM}$ menadione을 혼합하여 well에 $1 \mathrm{ml}$ 씩 첨가하 여 5분 동안 반응시킨 후, 반응 정지용액인 $10.3 \mathrm{mM}$ dicumar$\mathrm{ol}, 0.5 \%$ pyridine, $5 \mathrm{mM}$ potassium phosphate ( $\mathrm{pH} 7.4)$ 혼합 액을 $250 \mu \mathrm{l}$ 씩 첨가하여 효소반응을 정지시키고 Multi-detection microplate를 이용하여 $610 \mathrm{~nm}$ 에서 흡광도를 측정하 여 계산하였다. 그리고 단백질량은 동일한 set의 well plate에 대한 crystal violet 염색방법으로 정량하였다.

단백질량은 동일한 set의 well plate에 대한 crystal violet 염색 방법으로 정량하였다. 24 well plate에 $1 \times 10^{4}$ cells/well 농도로 분주하고, $37^{\circ} \mathrm{C}, 5 \% \mathrm{CO}_{2}$ incubator에서 2시간 배양한 후 증류수로 2분간 세척하였다. 각 well에 $0.5 \%$ SDS (in 50\% $\mathrm{EtOH}$ ) 용액을 $1 \mathrm{ml}$ 씩 가하여 $37^{\circ} \mathrm{C}$ incubator에 1 시간 방치한
후 $610 \mathrm{~nm}$ 에서 흡광도를 측정하였다.

Quinone reductase 활성측정 $(\mathrm{nmol} / \mathrm{min} / \mathrm{mg}$ protein)은 다 음과 같이 하였다.

* Specific quinone reductase (QR) activity

$$
=\frac{\text { absorbance change of MTT } / \mathrm{min}}{\text { absorbance of crystal violet }} \times 3345 \mathrm{nmol} / \mathrm{mg}
$$

\section{통계처리}

본 실험에 대한 실험결과는 세 번 실험하여 얻어진 평균치 및 표준편차를 나타내었고, 그룹간의 통계적 차이는 student's t-test를 이용하여 분석하였다.

\section{결과 및 고찰}

\section{군소내장의 각 용매별 분획물 수율}

군소내장은 동결 건조 후 메탄올을 1:5 (W/V)의 비율로 첨 가한 후 상온에서 2회 추출하고, 극성과 비극성으로 선별물질 을 추출하기 위하여 다시 메탄올과 다이클로로메탄 $\left(\mathrm{CH}_{2} \mathrm{Cl}\right)$ 을 1:1로 섞은 용매에 2회 추출하여 군소내장 추출물 $(\mathrm{AKM}) 23.62$ $\mathrm{g}$ 을 얻고, 이 추출물을 분획하여 hexane층 $(\mathrm{AKMH}) 1.44 \%$, methanol층(AKMM) 4.36\%, butanol층(AKMB) $2.88 \%$ 및 aqueous층(AKMA) $46.87 \%$ 를 수득하였으며, 각 시료의 용매 별 수득율은 Table 1 과 같다.

\section{군소내장 분획물의 암세포 성장 억제 효과 측정}

본 실험에서는 간암 세포인 HepG2, 유방암 세포인 MCF-7, 대장암 세포인 HT-29 및 피부암세포주인 B16-F10 를 이용하 여 군소내장 분획물에 대한 각 암세포주의 성장 억제 효과를 MTT assay를 이용하여 알아보았다. Fig. 1은 HepG2 세포주에 대한 실험 결과이며 군소내장 분획물의 암세포 성장 억제 효 과는 $\mathrm{AKMM}$ 층에서 가장 높은 억제 효과를 나타내었다. 150 $\mu \mathrm{g} / \mathrm{ml}$ 의 농도에서 $77.26 \%$ 의 억제 효과를 나타내었고, $250 \mu \mathrm{g} /$ $\mathrm{ml}$ 농도에서는 $84.57 \%$ 의 가장 높은 암세포 성장 억제 효과를 나타내었다. 다음으로 $\mathrm{AKMB}$ 층에서 암세포 성장 억제 효과를 나타내었으며 $250 \mu \mathrm{g} / \mathrm{ml}$ 농도에서 $56.55 \%$ 의 다소 낮은 억제

Table 1. Yields(\%) of various solvent fractions of internal organs of Aplysia kurodai (AK)

\begin{tabular}{ccc}
\hline Fractions & Yields $(\mathrm{g})$ & Yields $(\%)$ \\
\hline Methanol ex. & 23.62 & 23.62 \\
Hexane fr. & 0.34 & 1.44 \\
Methanol fr. & 1.03 & 4.36 \\
n-Butanol fr. & 0.68 & 2.88 \\
Aqueous fr. & 11.07 & 46.87 \\
\hline
\end{tabular}

ex: extract, fr: fraction 


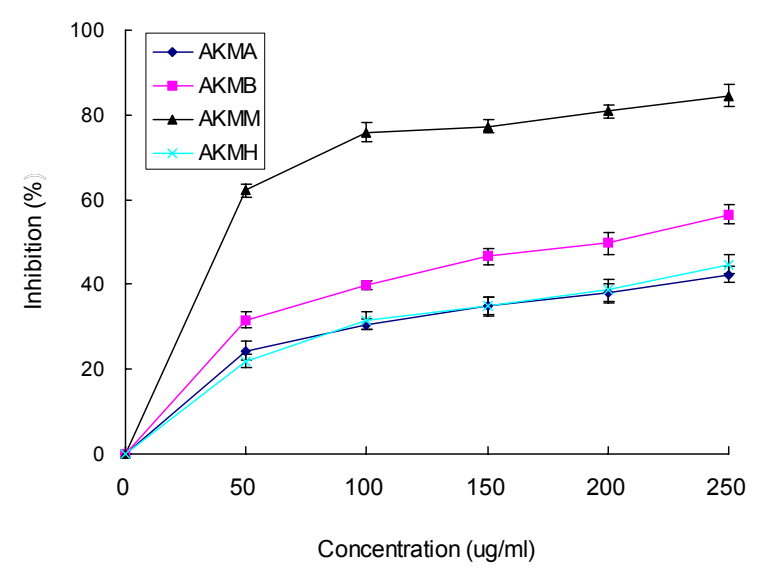

Fig. 1. Inhibitory effects on cell survival of various partition laye rs of internal organs of Aplysia kurodai (AK) on HepG2 cells. AKMM: Methanol partition layer of methanol extra cts of internal organs of Aplysia kurodai (AKM), TIMH: Hexane partition layer of AKM, AKMB: Butanol partition layer of AKM, AKMA: Aqueous layer of AKM.

효과를 나타내었다. 그리고 $\mathrm{AKMH}$ 층과 $\mathrm{AKMA}$ 층의 암세포 성장 억제 효과는 거의 비슷한 효과를 보였으며 최종농도인 $250 \mu \mathrm{g} / \mathrm{ml}$ 농도에서도 각각 $44.80 \%$ 와 $42.38 \%$ 의 수치를 나타 내어 매우 낮은 효과를 나타내었다. Fig. 2는 MCF-7 세포주에 대한 결과로서 $\mathrm{HepG} 2$ 에서와 마찬가지로 $\mathrm{AKMM}$ 층에서 가 장 높은 억제 효과를 나타내어 $250 \mu \mathrm{g} / \mathrm{ml}$ 농도에서 $79.65 \%$ 의 효과를 나타내었으며, 다음으로 $\mathrm{AKMB}$ 층에서는 $250 \mu \mathrm{g} / \mathrm{ml}$ 농 도에서 $55.85 \%$ 의 억제효과를 나타내었다. 그리고 $\mathrm{AKMH}$ 층에 서는 조금 더 낮은 $47.16 \%$ 의 암세포 성장 억제 효과를 나타내 었으며, $\mathrm{AKMA}$ 층에서는 최종 농도인 $250 \mu \mathrm{g} / \mathrm{ml}$ 농도에서도 가장 낮은 $41.95 \%$ 의 암세포 성장 억제 효과를 나타내었다. Fig. 3은 HT-29 세포주에 대한 결과로서 앞의 결과에서와 같이 $\mathrm{AKMM}$ 층에서 가장 높은 억제 효과를 보였다. 즉, $250 \mu \mathrm{g} / \mathrm{ml}$

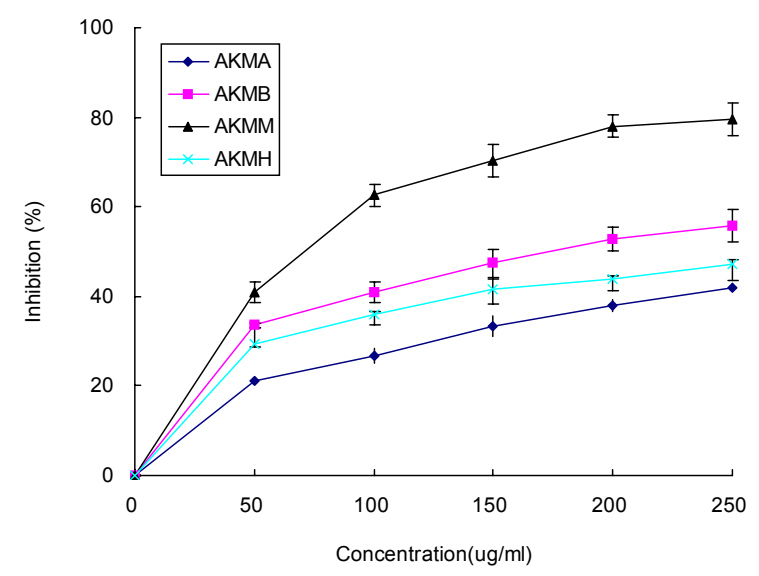

Fig. 2. Inhibitory effects on cell survival of various partition laye rs of internal organs of Aplysia kurodai on MCF-7 cells.

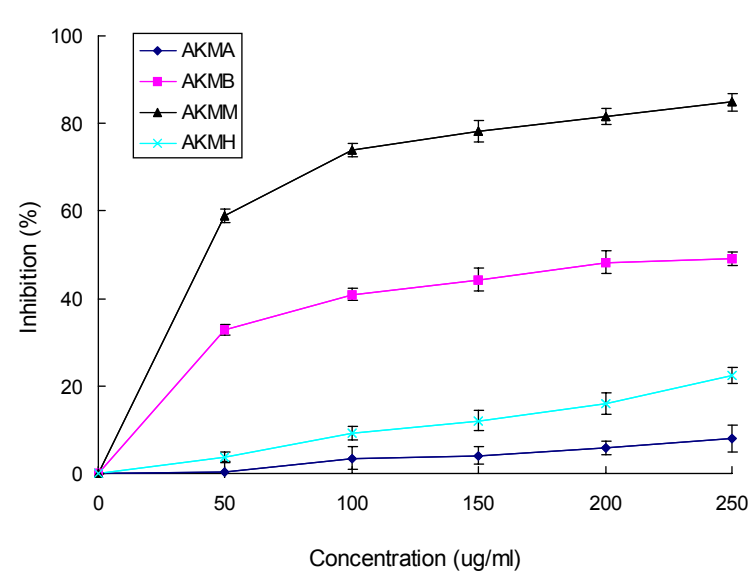

Fig. 3. Inhibitory effects on cell survival of various partition laye rs of internal organs of Aplysia kurodai on HT-29 cells.

의 최종농도에서 $\mathrm{AKMM}$ 층이 $84.86 \%$ 의 가장 높은 암세포 억 제 효과를 나타내었으며, 다음으로 $\mathrm{AKMB}$ 층에서 $48.97 \%$ 의 억 제효과를 나타내었고, $\mathrm{AKMH}$ 층과 $\mathrm{AKMA}$ 층에서는 $22.47 \%$ 와 $8.05 \%$ 의 아주 낮은 암세포 성장 억제 효과를 나타내었다. Fig. 4는 B16-F10 세포주에 대한 결과로서 앞의 HepG2, MCF-7 및 HT-29 세포주에서와 마찬가지로 $\mathrm{AKMM}$ 층에서 가장 높은 억 제 효과를 보였다. 특히 B16-F10 세포주에서는 $100 \mu \mathrm{g} / \mathrm{ml}$ 의 농도에서 이미 $85.99 \%$ 의 억제효과를 나타내었고 $150 \mu \mathrm{g} / \mathrm{ml}$ 의 농도에서 $92.89 \%, 250 \mu \mathrm{g} / \mathrm{ml}$ 농도에서는 $94.12 \%$ 의 억제효과 를 보여 앞의 HepG2, MCF-7 및 HT-29 세포주에 비해 가장 높은 암세포 성장 억제 효과를 나타내었다. 4 가지 암세포주에 미치는 군소내장 분획물의 암세포 성장 억제에 대한 실험 결 과에서 methanol 분획층인 $\mathrm{AKMM}$ 층에서 그 효과가 가장 높 게 나타났으며 다음으로 butanol 분획층인 $\mathrm{AKMB}$ 층에서 암세 포 성장 억제 효과를 나타내었고 hexane과 aqueous 분획층에 서는 유의성 있는 효과를 거의 볼 수 없었다. 이와 같은 결과는

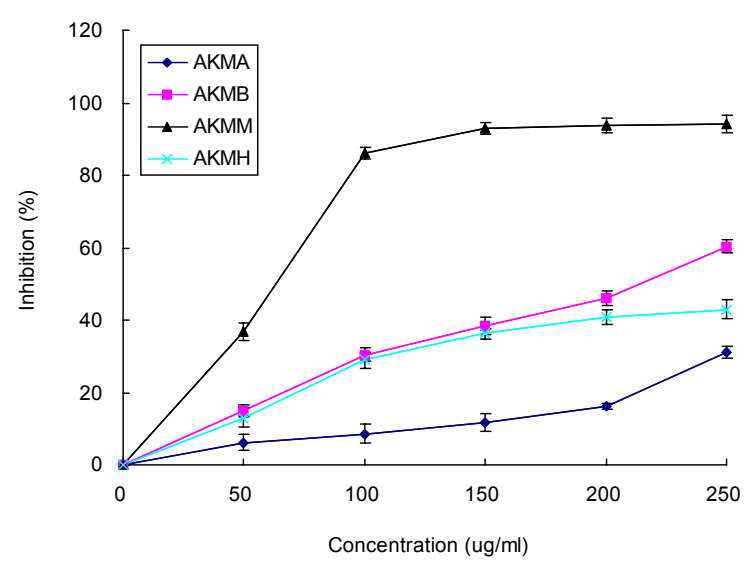

Fig. 4. Inhibitory effects on cell survival of various partition laye rs of internal organs of Aplysia kurodai on B16-F10 cells. 


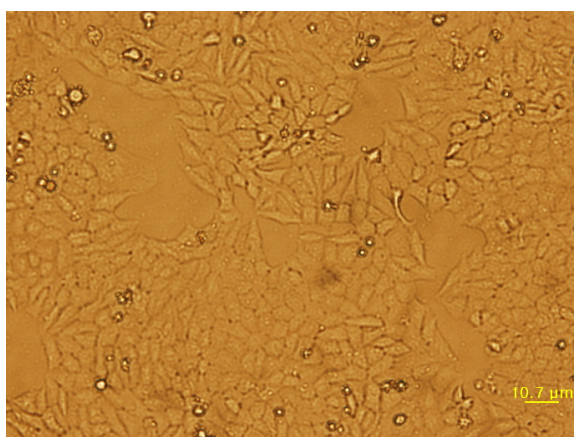

(A)

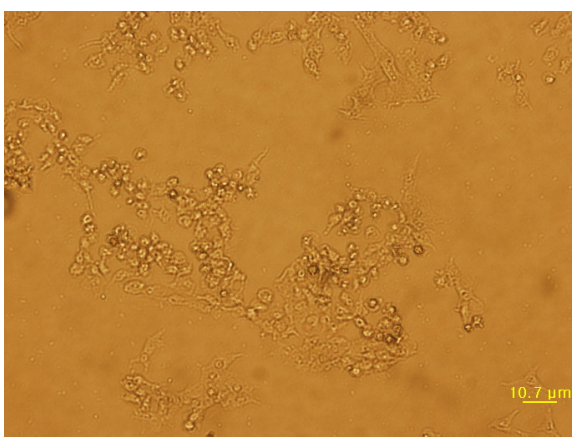

(C)

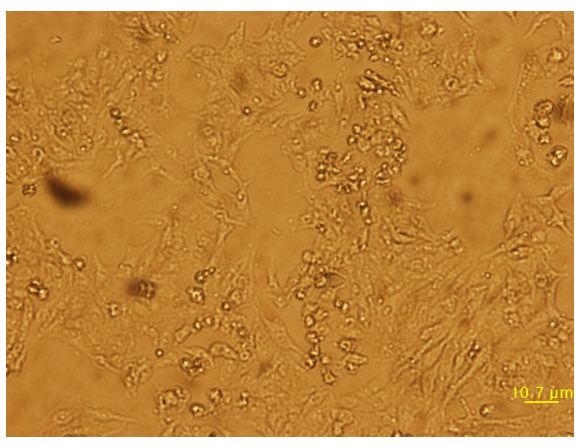

(B)

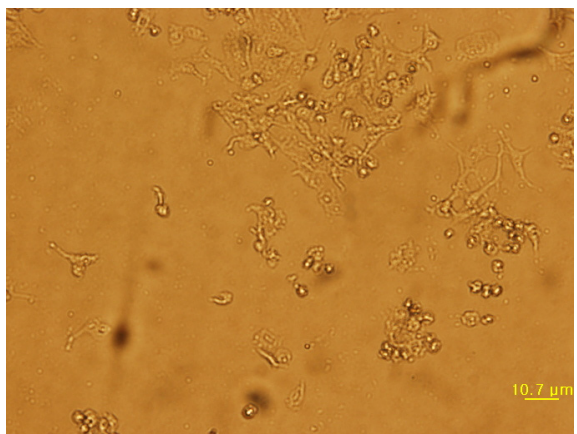

(D)

Fig. 5. Photomicrographs $(\times 200)$ of HepG2 cells on methanol partition layers of internal organs of Aplysia kurodai. (A) Control. (B) AKMM $50 \mu \mathrm{g} / \mathrm{ml}$ (C) AKMM $150 \mu \mathrm{g} / \mathrm{ml}$ (D) AKMM $250 \mu \mathrm{g} / \mathrm{ml}$

본 실험실에서 연구되어진 키조개, 참치지느러미 등의 해양 동물과 대부분의 해조류가 모두 methanol 분획층에서 가장 높은 암세포 성장 억제 효과를 나타낸 결과[17,22,28,31]와 일 치하였으나 오징어내장과 말똥성게 분획물이 hexane 분획층 에서 가장 높은 암세포 성장 억제 효과를 나타낸 결과와 [29,30]는 다른 결과에 해당된다. 그리고 시료의 농도를 비교 해 볼 때, 키조개와 말똥성게의 암세포 성장 억제효과와 비 슷하였고 특히, 폐기되어지는 부산물인 오징어내장의 결과 와 비교해볼 때 오징어내장 시료농도의 약 $1 / 2$ 에 해당되는 농도에서 유사한 효과를 나타내어 오징어내장에 비해서는 높은 암세포 성장 억제 효과를 확인할 수 있었다[23,29.30]. 이상으로 암세포 성장 억제 효과를 일으키는 군소내장의 생 리활성 물질은 methanol 분획층에 주로 존재한다고 추측해 볼 수 있었으며 앞으로 이들 분획층에서의 암세포 성장을 억 제하기위한 기능성 물질의 존재가 기대되어진다. 그리고 실 험에 사용한 세포주들을 비교해 볼 때, $\mathrm{AKMM}$ 층이 피부암 세포주에서 가장 높은 억제효과를 나타내었으며 다음으로 대장암, 간암 및 유방암 순으로 억제효과를 나타내었다. 앞으 로 더욱 심도 있는 연구를 통해 이들 분획층의 생리 활성물 질들을 규명하고 구조와 그 기전들을 알아보는 연구가 진행 되어야 한다고 생각된다.

\section{$\mathrm{AKMH}$ 층의 처리에 따른 암세포의 형태학적 변화}

암세포 성장 억제 효과에서 가장 높은 효과를 나타낸 meth$\mathrm{anol}$ 분획층인 $\mathrm{AKMM}$ 층의 처리가 암세포의 형태에 어떠한 영향을 주는지 알아보기 위해 각 세포주에 여러 농도의 $\mathrm{AKMM}$ 층을 48시간 동안 처리한 후 위상차현미경으로 형태학 적인 관찰을 하였다. Fig. 5는 HepG2 세포주에 농도별로 시료 를 첨가한 후의 세포형태의 변화를 관찰한 결과이다. 시료 농 도의 증가에 따라 의존적으로 현저한 세포 밀도의 감소현상과 세포막의 shrinking 및 blebbing 현상 등의 형태학적 변화가 나타났으며 암세포들의 부착력 상실과 파괴된 세포 잔여물들 이 뚜렷하게 관찰되었다.

\section{Quinone reductase 유도 활성 증가 효과}

본 연구에 사용된 quinone reductase (QR)는 phase II 무독 화 효소중의 하나로 돌연변이 또는 발암물질 등에 의한 DNA 와의 상호작용을 차단하는 효소이며 $\mathrm{NAD}(\mathrm{P}) \mathrm{H}$ 를 이용하여 quinone류의 환원을 촉매하는 flavoprotein의 일종이다. 특히 $\mathrm{QR}$ 은 phase 피효소계의 지표효소로서 다양한 종류의 항암물 질에 의해 그 활성이 유도되어 암예방을 선도하는 특성을 가 지고 있어서 암 예방 물질의 탐색에 많이 사용되어 왔다 $[9,25,26]$. 암세포 성장 억제 효과에 사용된 4 종의 암세포 중 
유일하게 quinone reductase를 가지고 있는 간암 세포인 $\mathrm{HepG} 2$ 세포주를 사용하여 군소내장의 $\mathrm{QR}$ 유도 활성 증가 효과를 측정하였으며 그 결과는 Fig. 6 과 같다. HepG2 암세포 주에 대한 용매별 군소내장 분획물을 각각 $20,40,60,80$ 및 $100 \mu \mathrm{g} / \mathrm{ml}$ 씩 첨가했을 때, $\mathrm{AKMM}$ 층이 가장 높은 효과를 보 인 암세포 성장 억제 효과의 결과와 같이 $\mathrm{AKMM}$ 층에서 가장 높은 $\mathrm{QR}$ 유도 활성 증가 효과를 나타내었다. 대조군을 1 로 했 을 경우 $\mathrm{AKMM}$ 층에서 그 효과가 농도 의존적으로 유의성 있 게 증가하였으며 $40 \mu \mathrm{g} / \mathrm{ml}$ 첨가 했을 때 이미 2.0 배의 $\mathrm{QR}$ 유도 활성 증가 효과를 보였고 $80 \mu \mathrm{g} / \mathrm{ml}$ 첨가 했을 때 2.2배 그리고 최종농도인 $100 \mu \mathrm{gg} / \mathrm{ml}$ 첨가 했을 때에는 대조군에 비해 $\mathrm{AKMM}$ 층이 2.4배의 높은 $\mathrm{QR}$ 유도 활성을 나타내었다. 그러 나 다른 모든 분획층에서는 대부분 1 에 가까운 수치를 나타내 어 $\mathrm{QR}$ 유도 활성 증가 효과를 거의 볼 수 없었다. 이상의 결과 에서 군소내장 분획물 중 $\mathrm{AKMM}$ 층에서 가장 높은 유의성 있 는 $\mathrm{QR}$ 유도 활성을 보였으므로 methanol 분획층인 $\mathrm{AKMM}$ 층 에서 암 예방 효소계인 quinone reductase의 inducer가 주로 존재함을 추정할 수 있었다. 이러한 결과는 본 연구실에서 연 구된 다른 시료들과 비교해 볼 때, 키조개[23], 참치지느러미 [28], 오징어내장[29] 등의 해양생물이 주로 메탄올 분획층에 서 가장 높은 $\mathrm{QR}$ 활성 효과를 나타낸 결과와 일치하였고, 시료 의 농도를 비교하여 볼 때 최저농도인 $20 \mathrm{\mu g} / \mathrm{ml}$ 에서 이미 1.7 배의 $\mathrm{QR}$ 유도 활성을 나타내어 위의 해양 동물 중 가장 높은 $\mathrm{QR}$ 유도 활성 효과에 해당되었다. 특히, 폐기되어지는 부산물 인 오징어내장[29]의 실험결과와 비교해볼 때 오징어내장은 시료 최종농도인 $270 \mathrm{\mu g} / \mathrm{ml}$ 에서 2배의 효과를 보여 군소내장

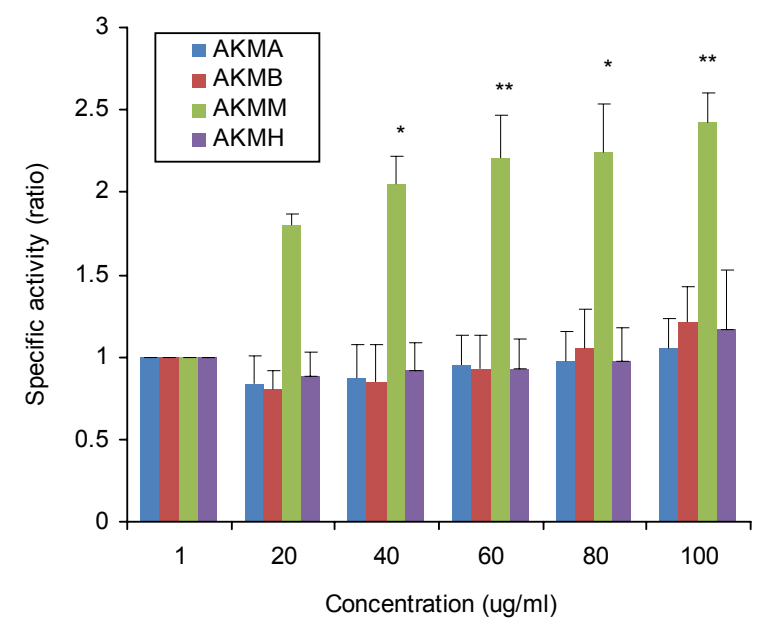

Fig. 6. Effects of various partition layers of internal organs of Aplysia kurodai on the induction of quinone reductase in HepG2 cells. Cells were cultured at a starting density of $1 \times 10^{4}$ cells $/ \mathrm{ml}$ in DMEM. values are represented mean \pm SD of 3 repeats. Significantly different by t-test: ${ }^{*} p<0.05,{ }^{* *} p<0.01$ vs. control.
의 $\mathrm{QR}$ 유도 활성효과는 매우 높다고 할 수 있다. 앞으로 더욱 더 심도 있는 연구를 통해 군소내장 분획물중 methanol 분획 층인 $\mathrm{AKMM}$ 층에서의 생리활성 물질을 추적, 보완하여 그 구 조를 동정함으로서 식품산업에 있어서의 암 예방 효과를 지닌 기능성 식품개발에 매우 중요한 자료가 될 수 있을 것으로 사료된다.

\section{References}

1. Alley, M. C., D. A. Scudiero, A. Monks, M. L. Hursey, M. J. Czerwinski, D. L. Fine, B. J. Abbortt, J. G. Mayo, R. H. Shoemarker, and M. R. Boyd. 1988. Feasibility of drug screening with panels of human tumor cell lline using a microculture tetrazolium assay. Cancer Res. 48, 589-601.

2. Bae, M. J., S. T. Yee, S. Y. Chae, S. H. Shin, S. H. Kweon, M. H. Park, M. K. Song, and S. J. Hwang. 2004. The effect of arabinoxylane and the polysaccharide peptide (PSP) on the antiallergy, anticancer. J. Korean Soc. Food Sci. Nutr. 33, 469-474.

3. Banner, S. E., U. Pastorino, S. M. Lippman, and W. K. Hong. 1994. Second international chemoprevention conference. Cancer Res. 54, 854-860.

4. Budd, G. T., B. Osgood, B. Barna, I. M. Boyett, J. Finke, S. V. Mdendrop, S. Murth, and R. M. Bukoski. 1989. Phase I clinical trial Toxicity and immunologic effects, Cancer Res. 49, 6432-6439.

5. Carmichael, J., W. G. De Graff, A. F. Gazder, J. D. Minna, and J. B. Mitchell. 1987. Evalution of the tetrazolium based semiautomated colorimetric assay: assessment of chemosensitivity testing. Cancer Res. 47, 936-942.

6. Cha, B. C., H. W. Lee, and M. Y. Cho. 1998. Antioxidative and antimicrobial effeats of nut species. Kor. J. Pharmacogn. 29, 28-34

7. Choe, B. L. and J. R. Lee. 1994. Opisthobranchs (mollusca: gastropoda) from ullung and dog-do islands, korea. Korean J. Zool. 37, 352-376.7. Giampietri, A. 1981. Drug-mediated increase of tumor immunogenicity in vivo for a new approach to experimental cancer immunotherapy. Cancer Res. 41, 681-685.

8. Giampietri, A. 1981. Drug-mediated increase of tumor immunogenicity in vivo for a new approach to experimental cancer immunotherapy. Cancer Res. 41, 681-685.

9. Hong, E. Y., H. J. Kang, C. S. Kwan, Y. J. Na, M. J. Suh, and J. S. Kim. 1997. Modulation of cellular quinone reductase inducibility by roasting treatment and acid hydrolysis of perilla. J. Korean Soc. Food Sci. Nutr. 26, 186-192.

10. Jung, Y. H., B. M. Jung, M. O. Shin, and S. J. Bae. 2006. A study on the effects of anticarcinogenic activity of gloiopeltis tenax. J. Korean Soc. Food Sci. Nutr. 35, 395-401.

11. Kandel, E. R., J. H. Schwartz, and T. M. Jessell. 2000. Principles of neural science, 4th eds. McGraw-Hill, New York, 180.

12. Kim, C. H., H. J. Seo, E. Y. Hwang, E. J. Kim, H. J. Go, I. H. Kim, J. K. Seo, J. H. Moon, M. D. Huh, and N. G. 
Park. 2001. Purification of myomoduline A and myomodulin E from the central nervous system of the sea lare, Aplysia kurodai. J. Korean Fish Soc. 34, 279-284.

13. Kim, H. S. and B. L. Choe. 1981. The founa of marine invertebrate in ulreung is. and dog-do is. special report. The Conservation of Nature and Natural Resources 19, 193-200.

14. Kim, J. S. 2005. Cancer chemoprevention and NSAID-activated gene (NAG-1). Biochemistry and Molecular Biology News 12, 286-291.

15. Lee, J. S. and D. K. Min. 2002. A catalogue of molluscan fauna in Korea. Opisthobranchs 18, 93-97.

16. Lee, Y. S., D. S. Kim, B. H. Ryu, and S. H. Lee. 1992. Antitumor and Immunodulating effect of seaweeds toward sarcoma-180 cell. J. Korean Soc. Food Sci. Nutr. 21, 544-550.

17. Lloyd, P. E., I. Kuufermann, and K. R. Weiss. 1987. Sequence of small cardioactive peptide A: A second member of a class of neuropeptides in Aplysia. Peptides 8, 179-184.

18. Morris, H. R., M. Panico, A. Karplus, P. E. Lloyd, and B. Riniker. 1982. Elucidation by FAB-MS of the structure of a new cardioactive peptide from Aplysia. Nature 300, 643-645.

19. Nishiwaki, S., H. Ueda, and T. Makioka. 1975. Tagging studies on the growth of the sea hare Aplysia kurodai on an intertidal rocky shore. Marine Biology 32, 389-395.

20. Park, H. J. 1998. Induction of quinone reductase and its regulatory mechanism at the transcriptional level by Scutellaria baicalensis, Ph. D. Dissertation, Yonsei University, Seoul.

21. Park, J. C. and J. W. Choi. 1996. Screening of marine natural products on inhibitory effect of the formation of lipid peroxidation. Kor. J. Pharmacogn. 27, 117-122.

22. Park, S. Y., B. M. Jung, Y. H. Choi, and S. J. Bae. 2005. Growth inhibition effects of cancer cell lines by gloiopeltis furcata fractions in vitro. J. Korean Soc. Food Sci. Nutr. 34, 771-775.

23. Park, Y. J., M. O. Shin, S. H. Lee, and S. J. Bae. 2005. The growth inhibitory effects of atrina pecitinata fractions on cancer cell lines. Korean J. Nutrition 38, 307-312.

24. Prochaska, H. J. 1994. Screening strategies for the detection of anticarcinogenic enzyme inducers. J. Mutr. Biochem. 5, 360-370.

25. Prochaska, H. J., A. B. Santamaria, and P. Talalay. 1992. Rapid detection of inducers of enzyme that protect against carcinogene. Proc. Natl. Acad. Sci. USA 89, 2394-2399.

26. Prochaska, H. J. and A. B. Santamaria. 1988. Direct measurement of $\mathrm{NAD}(\mathrm{P}) \mathrm{H}$ : Quinone reductase from cells cultured in microtiter wells : A screening assay for anticarcinogenic enzyme inducers. Anal. Biochem. 169, 328-336.

27. Schwartsmann, G., A. B. Roch, R. G. Berlinck, and J. Jimeno. 2001. Marine organisms as a source of new anticancer agents. Oncology 2, 221-225.

28. Shin, M. O., M. J. Ku, and S. J. Bae. 2007. Cytotoxicity and quinone reductase activity stimulating effects of fin of thunnus thynnus extracts in various cancer cells. Korean J. Nutrition 40, 147-153.

29. Shin, M. O. and S. J. Bae. 2009. Growth inhibitory and quinone reductase activity stimulating effects of internal organs of todarodes pacificus fractions on human cancer cell lines in vitro. J. Life Science 19, 1251-1257.

30. Shin, M O. and S. J. Bae. 2009. The anticarcinogenic and antioxidative activity of Hemicentrotus pulacherrimus fractions in various cancer cells. J. Life Science 19, 607-614.

31. Shon, J. H., D. Y. Kang, H. C. OH, B. M. Jung, M. H. Kim, M. O. Shin, and S. J. Bae. 2006. The effects on antimicrobal and cytotoxicity of hijikia fusiformis fraction. J. Korean Soc. Food Sci. Nutr. 39, 444-450.

32. Shon, Y. H., K. H. Jeune, and S. J. Choi. 1998. Chung S. R. Life Science; Antitumor effect of asterina pecinifera lectin on ascitic tumor. Yakhak Hoeji 42, 99-105.

33. Tusa, Y. 1994. Size-related egg production in a simultaneous hermaphrodite, the sea hare Aplysia kurodai baba (mollusca: opisthobranchia). Publ. Seto Mar. Biol. 36, 249-254.

34. Wefers, H., T. Komai, P. Talalay, and H. Sies. 1984. Protection against reactive oxygen species by $\mathrm{NAD}(\mathrm{P}) \mathrm{H}$ : quinone reductase induced by the dietary antioxidant butylated hydroxyanisole (BHA). Federation of European Biochemical Societies 169, 63-66. 


\section{초록 : 군소내장 분획물의 in vitro에서의 암세포 성장억제 및 quinone reductase 유도 활성 증가 효과}

신 미 옥*

(신라대학교 식품영양학과)

본 연구에서는 군소내장을 각 용매별로 분획하여 암세포 성장 억제 효과와 quinone reductase $(\mathrm{QR})$ 유도 활성 증가 효과를 알아보았다. 간암 세포인 HepG2, 유방암 세포주인 MCF-7, 대장암 세포주인 HT-29 그리고 피부암 세포주인 B16-F10 를 이용하여 암세포 성장 억제 효과를 실험한 결과 모든 세포주에서 AKMM층에서 농도 의존 적으로 가장 높은 암세포 성장 억제 효과를 나타내었다. 그리고 다음으로 $\mathrm{AKMB}$ 층, $\mathrm{AKMH}$ 층 및 $\mathrm{AKMA}$ 층의 순이었다. 그리고 4종의 암세포주 중에서 B16-F10 세포주가 가장 높은 암세포 성장 억제 효과를 나타내어 특히 피부암에 대한 예방효과가 기대되어진다. 또한 암 예방 효과를 알아보기 위하여 4종의 암세포 중 유일하게 quinone reductase를 가지고 있는 인체 간암세포주인 $\mathrm{HepG} 2$ 를 이용하여 $\mathrm{QR}$ 유도 활성 증가 효과를 측정한 결과, 암세포 성장 억제 효과에 있어서 가장 높은 효과를 나타낸 $\mathrm{AKMM}$ 층에서 가장 높은 $\mathrm{QR}$ 유도 활성 증가 효과를 나타내었다. 그러나 다른 분획층에서는 $\mathrm{QR}$ 유도 활성 증가 효과를 거의 볼 수 없었다. 이상으로 암세포 성장 억 제 효과와 $\mathrm{QR}$ 유도 활성 효과에서 모두 methanol 분획층인 $\mathrm{AKMM}$ 층에서 가장 높게 나타났으므로 이 분획층에 유효한 생리활성 물질이 함유되어 있을 가능성이 추정되어진다. 따라서 폐기되어지는 군소부산물인 내장을 이용 한 암 예방 관련 기능성 식품의 개발 가능성이 기대되어지며, 이를 위한 AKMM분획층에 대한 더욱더 심도 높은 집중적인 연구가 요구되어진다. 